\title{
РИСИ ПОДІЛЬСЬКОГО ГОВОРУ В РУКОПИСНІЙ СПАДЩИНІ М. КОЦЮБИНСЬКОГО
}

\author{
БОРИС КОВАЛЕНКО \\ Кам’янець-Подільський національний університет імені Івана Огієнка, \\ Кам’янець-Подільський — Україна \\ CECHY GWARY PODOLSKIEJ \\ W RĘKOPIŚMIENNEJ SPUŚCIŹNIE M. KOCIUBYNSKIEGO
}

\section{BORYS KOWALENKO}

Uniwersytet Narodowy im. Iwana Ohijenki w Kamieńcu Podolskim, Kamieniec Podolski — Ukraina

STRESZCZENIE. W artykule scharakteryzowano osobliwości językowe rękopisów utworów literackich M. Kociubynskiego tworzonych na przestrzeni lat. Ustalono, że we wczesnych tekstach pisarza pojawia się znacznie więcej form gwarowych, aniżeli w jego późniejszych opowiadaniach. Wraz z rozwojem i doskonaleniem własnego stylu pisarz starał się zamieniać formy dialektalne na literackie.

\section{FEATURES OF PODILLYA DIALECT IN MANUSCRIPT HARRITAGE OF M. KOTSYUBYNSKIY}

BORYS KOVALENKO

Ivan Ohiyenko Kamyanets-Podilskiy State University, Kamyanets-Podilskiy — Ukraine

ABSTRACT. In the article the linguistic features of M. Kotsyubynskiy's manuscripts written in different years are characterized. It is specified that in first author's literary attempts there were more dialectal features than in later ones. The writer, while developing and improving his style, tried to change dialectal forms into literary ones.

овотворчість М. Коцюбинського є вершиною української прози кінця XIX - початку XX ст., „видатним явищем у розвитку української літературної мови загалом, що підняла їі на вищий ступінь якості, розширила структурно-стилістичні і конкретні художні та науково-публіцистичні засоби виразу в галузі лексики, фразеології, синтаксису"1. Значною була роль письменника і в розвитку української лінгвістики. Міркування про українську мову він виклав у літературно-критичних і публіцистичних працях, листах, у яких обстоював вільне, різностильове функціонування української мови, критикував помилкові, консервативні погляди на українську мову. М. Коцюбинський писав про мову творів І. Котляревського, Т. Шевченка, П. Куліша, І. Нечуя-Левицького та ін., окреслив джерела й шляхи збагачення літературної мови, висловив слушні міркування з питань лінгвостилістики, правопису тощо 2.

${ }^{1}$ І . К. Бі ло ді д, Мова творів М. Коцююбинського, [в:] Курс історії украӥнської літературної мови: Дожсовтневий період, Київ 1958, т. 1, с. 519.

${ }^{2}$ В. М. Статєєва, Коцฺюбинський Михайло Михайлович, [в:] Украйнська мова: Еничиклопедія, редкол.: В. М. Русанівський, О. О. Тараненко та ін., Київ 2004, с. 278-279. 
Перший етап „канонізації” М. Коцюбинського, на думку Я. Поліщука, припадає ще на 20-ті роки XX ст., коли було „впорядковано твори прозаїка, звірено їx із першодруками (очевидно, не без помилок та суперечностей, пов'язаних 3 утручанням дореволюційної цензури), зібрано унікальний архів спогадів"з Творчість письменника в різні часи досліджували Н. Бажан, М. Богдан, В. Дроздовський, С. Сфремов, М. Зеров, В. Калашник, С. Козуб, Д. Колесник, В. Масальський, Л. Мацько, Н. Над’ярних, Л. Паламарчук, П. Плющ, П. Филипович та ін.

Мова творів письменника не перестає бути предметом різнопланових наукових праць і до сьогодні.

Мета статті — виявити й проаналізувати вияв рис подільського говору в рукописній спадщині М. Коцюбинського. Як зауважував П. Тимошенко, „вивчення мовних (фонетичних, морфологічних та ін.) особливостей мови письменниківкласиків необхідне як у практичному, так і в теоретичному відношеннях. Воно потрібне насамперед для з'ясування загальних тенденцій розвитку літературної мови в минулому, становлення іï норм, що, відповідно, дає змогу визначити основу нормативних кодексів сучасної української літературної мови"4.

У процесі підготовки цієї наукової розвідки використано такі автографи М. Коцюбинського: p-1 — "Андрій Соловійко або вченіе свит, а невченіе тьма", p-2 — "21 грудня, на введеніє", p-3 — “Дядько та тітка", p-17 — “Ялинка", p-18 — "Харитя", p-55 — "Хмари", p-56 — "Утома", p-69 — "Він іде", p-197 — “Подарунок на іменини”, p-199 — “Коні не винні”, p-202 — "На острові”, що зберігаються у відділі рукописів Чернігівського літературно-меморіального музею-заповідника Михайла Коцюбинського. Матеріалом дослідження обрано автографи письменника, оскільки автор цієї статті схиляється до думки П. Гриценка, який зауважує, що „необхідність спиратися у лінгвістичних студіях на історію тексту залишається актуальною під час вивчення ідіолекту письменника, особливостей мови його творів”, а „некритичний вибір варіанта тексту для вивчення мови художнього твору, ідіолекту письменника як цілості чи для укладання словника мови його творів, призводить до прорахунків дослідників"5. У працях дослідників мовотворчості М. Коцюбинського, аналіз яких грунтується на текстах різних років видання, натрапляємо на протилежні думки, зокрема К. Дорошенко зауважував, що „мова ранніх творів письменника рясніє діалектизмами", а І. Білодід, прагнучи створити мовний портрет письменника в контексті історії української літературної мови, вивчав мову його творів за виданням 1950-го року й зазначав, що в „мові ранніх оповідань письменника діалектизмів більше, ніж у пізніших творах < ..> проте вони не ,рясніють” у мові оповідань і цього, раннього періоду”7. Наголошуючи, що „мова М. Коцюбинського як своїм словниковим складом, так і граматичною будовою цілком входить у норми сучасної української літературної мови”, вчений все ж таки виділяє деякі риси, що „становлять особливість мови письменника і свідчать про наявну в той час неунормованість літературної мови в певних галузях".

${ }^{3}$ Я. Поліщук, I ката, і героя він любив...: Михайло Коиюбинський: літературний портрет, Київ 2010, с. 10.

${ }^{4}$ П. Д. Ти мо ше н ко, Морфологічні риси мови творів Шевченка (Іменник), [в:] Збірник праць XV наук. шевченків. конф., Київ 1968, с. 133.

${ }^{5}$ П.Ю.Гри и ен ко, Ідіолект і текст, [в:] Лінгвостилістика: об’єкт - стиль, мета оцінка, Збірник наук. праџь, присв. 70-річчю від дня народж. проф. С. Я. Срмоленко, Київ 2007, с. 20.

${ }^{6}$ К. П. До рошен ко, Мова і стиль повісті “Фата моргана” М. Коиюбинського, Київ, 1951, c. 8 .

${ }^{7}$ I. К. Білоді д, указ. джерело, с. 523.

${ }^{8}$ Там само, с. 549. 
Аналіз рукописної спадщини М. Коцюбинського уповноважує, по-перше, розширити перелік мовних особливостей, поданих у „Курсі історії української літературної мови”, по-друге, простежити динаміку мови письменника - від діалектного мовлення до літературного стандарту.

Проаналізувавши рукописи ранніх творів М. Коцюбинського, виділяємо такі риси подільського говору (проілюструємо найголовніші):

I. На фонетичному рівні:

1. В окремих словах деяких південно-західних говорів замість $[\mathrm{i}](<\mathrm{h})$ можуть мати місце й інші звуки: [i] внаслідок асиміляції до [у] в наступному складі може переходити в [у], що спостерігається, напр., у слові и̧ілувати цңюлювати: „Але Андрій швыдко нахилывся и перше, ниж Жук стямыився, поцюлював його руку, на котру разом з почюлюем капнуло дві горячи слёзы” (р-1); „Горяче, щыре сонце так и вабыть тебе, так, здается, й прымовляс, сяючы: „а ходы, чоловиче, най я обцюлюю тебе, з своими горячимы поцюлюнкамы увилью сылу в твое мизерне тило!'”' (р-3).

2. Уживання [и] на початку слів инчий, инак, иншу, исторія: „За розум, добре серце, чеснисть, щыру пораду и помич, вси люде з Босивки и ынчых сил казалы, що не зналы и не знают лучшого чоловика як Андрій Соловійко" (р-1); „Так чы bынак, а щось же іи допровадыло до такого нещасного стану” (р-2); „Було, и страву соби окреме ыншу варыть, и цукор свій тримає”; „Тепер також здоровенный, тилько декотри дерева повырублени, ынши посохлы, ынши здычавилы”; „БІсторыя, хозяйство, сыльныця, зирныця, землепысь, политычна економія, зоологія — все те на кону”; „... то зовсим ыншым чоловиком зробывся..." (p-3).

3. Випадіння звука або групи звуків у дієслові хотіти, в середині присудкового слова треба, в частці нехай - хтіти, тра, най: „Хтив бы розирваты увесь мыр, себе самого...”; „Тра шукаты якои небудь роботы...” (р-1); „Не прыймають... ходыла до сусидив — не хтять прийняты...”; „, Часом тра перейты через пекарню”; „Дайте, серце, най нагріюсь... Най я вже в вас переночую... Най я вже в вас, як в матеньки риднои...” (р-2); “... а ходы, чоловиче, най я обцюлюю тебе...”; „От лучше залышы та най твое пропадае”; „Тра було бачыты, як вин пеклувався, як вин побывався, як вин грызся, як титка була слаба. Тра було бачыты, кажу, бо ни сказаты, ни напысаты того нихто не здолае”; „Оприч казенщыны - там губернских та сенатских видомостей, — и у рукы ничого не хтилось узяты”; „То хтилось бы затаиты те невидоме счастя у самій глыбыни серця, то хтилось бы подилытыся ным 3 цилым свитом” (р-3); „- А лагодь, сину, сани, відвезеш ялинку. Та хапайся, сину, бо вже ген-ген з полудня, а тра вернутися завидна...” (р-17); „Почекаю, може, хто над’йіде та дасть мні яку раду, - подумав він, поглядаючи на дорогу, яку раз у раз замітав сніг" (p-17); „Вирядивши Василька, Яким легенько зітхнув: він продав ялинку за добрі гроші, а гроші були притьмом потрібні: тра було чоботи відібрати жінці від шевця і купити дещо на новий рік” (p-17); „Яким озирнувсь і не хтів вірити власним очам (р-17); „Завтра, іно розвидниться, встане Харитя, нагодує маму (коли $б$ ще схтіли йісти, а то відколи слабі - іно воду пьють), візьме серп і пійде на поле (p-18); „Ся думка не давала єі спокою. Йій хтілося скоріще діждатися ранку” (р-18); , - Ходім зараз до матері! Най вона втішиться, що має таку добру дитину...” (р-18).

4. Характерною ознакою подільського говору є стверділий кінцевий [т'] у дієсловах 3-ої особи однини і множини теперішнього часу і 2-ої особи множи- 
ни наказового способу: закрывают, почнут, нароблят, ненавылят, будут, любят, поважают, не знают, можут, засмиют, заглядают, радіют, мают, будут, бигают, прыймут, капают, бачыт, почнут, покинчат, скажут, чекают, пустит, знают, мают, пошлит, зеленіют, обступают тощо. У рукописах перших оповідань, хоч і не послідовно, але кінцевий [' ${ }^{\text {'] }}$ зазнає ствердіння, напр.: „... то буде жыття сыроты, котрого ненавылят”; „Хоцяж тебе не спіймалы, але можут спійняты”(р-1); „Пустит мене переночувати!..”; „Идни родяться у щасти, е що й исты, е в що вдягнутыся, і горя не знают, а други... отак марно гынуть...”; „Хиба Вы не знаете, що его вчора заризалы, а сегодня мают ховати, вже і люде зибралыся”; „Ну, то й пошлит, — кажу, — то й мені дасте”; „Зберайтеся, бабо, - каже мама, - та идит шукаты хаты на нич, а то пізно буде" (p-2); „Зеленіют проса... А з права и з лива обступают узгирья кучеряви стины густого зеленого лису...”; „И суд ничого не знае; панськи гроши всюде, паны адвокатив мают”; „От визьмит газеты та прочытайте. ... багато людей, а не иден, терпитемут вид его крывды...”; „Робит так, як я говорю, а не так, як я чыню”; „А йдит обидаты! Ото забалакалысь, - гукнула з ганку титка” (р-2).

5. Особливістю подільських говірок є наявність вставних приголосних [л], [н] після губних: здоровля, мнягко, соломляний тощо. Це явище також засвідчене в рукописах перших літературних спроб М. Коцюбинського, напр.: „Скильки воно уйняло в вас здоровля, счастя, скилько заграбало в тяжкій праци добутих, кровавих грошей?” (р-1); „Тыхо и мнягко казав Жук” (р-1); „В туж хвылыну, як вин оце подумав, у его ниг опынывся соломляный брыль, зирваный витром у якогось чоловика...” (p-1).

6. Типовою для подільського говору є твердість приголосного [р]: вечера, завіруха, ратунок, мрака тощо, наприклад: „Що ти робиш, доню? - поспитала мати. - Вечеру варитиму, мамо” (р-18); „На столі стоїть кутя. Батько та дві сестрички сидять за столом, мати подає вечеру. Всі такі веселі, гомонять, радіють божому святечку. Хлопці та дівчата приносять вечеру, поздоровляють 3 празником, питають про Василька... (р-17); , - Завіруха... та, може, ущухне... Повинен би Василько незабаром надйіхати” (р-17); „В тій чоловик шкрабается в голову, наче хоче выликрабаты з ній ту подать, що так мицно засила ёму в голову" (p-1). Хоча у цих же ранніх оповіданнях трапляється й м'який [р'] на місці нормативного [p]: теперь, бахуря, Сибирь, тюрьма, секретарь тощо.

7. Ще однією мовною рисою подолян є стягнення подвоєних приголосних. У рукописах ранніх оповідань, хоча й не послідовно, приголосні в іменниках середнього роду II відміни в позиції після голосних перед давнім закінченням -ьје не подовжуються, напр.: волося (але трапляється й волоссям), смитя, каминямы, шматя, оповіданя, йменя, весиля, тощо, напр.: „Не чоловик це, здавалось, ні звир, а щось такее, чому й йменя знайты трудно”(р-2); „Я перу шматя, колы прыходыть моя сестра, Устя” (р-2); „В своиім оповідани вона багато напутала” (p-2); „Густа, як щитка, зелена, як рута, заквичана, як дивчына на весили, манячыть трава на полянци” (р-3); „Жовтогарячій рипак аж горить на сонци, котре не шкодує свого проминя и на весь веселый краевыд” (p-3); „Кучерява сыва борода, не дуже велыка, кучеряви волося, румяный выд...” (p-3); „Василько похолов з остраху. Волося полізло до гори, серце перестало стукати в грудях" (р-17); „Босі ноженята ступали по втоптаній стежці, над головою, межи колосками жита синіло биндочкою небо, а з обох боків, як стіни, стояло жито й шелестіло вусатим колосям" (виправлено з колоссям - Б. К.) (p-18); „Довге стебло путається, великий серп не слухається в маленькій руці, коло- 
ся лоскоче впріле личенько...” (р-18). Спостерігаємо й відсутність подовжених приголосних в Ор. відм. одн. в іменниках ІІІ відміни: блакитю, синю, нічю, памятю, постатю, повіню, помічю, мідю тощо. Однак зазначимо, що в ранньому оповіданні Андрій Соловійко... після приголосних перед закінченням в орудному відмінку в іменниках III відміни, що закінчуються двома приголосними, послідовно вживається м'який знак або [i]: заздристію, хыжыстью, постилью, радистью, злистью, напр.: „Не иден проізжій гладкій пан ... 3 заздристію дівітся на таке сельце, любуется им...” (p-1); „Дытыни хтилось бы побавытыся 3 котом, що он пид постилью муркае, та так гарно простягае лапку до клубочка $з$ ныткою...” (p-1).

II. На морфологічному рівні:

1. Послідовно в ранніх оповіданнях М. Коцюбинський уживає закінчення -е в лексемі люди: „Други люде теж сказалы на Андрія, що вин непутящый” (p-1); „...его вчора заризалы, а сегодня мают ховати, вже і люде зибралыся”; „Варто б тому, хто хоче й може робыты добро людям - звернуты увагу и на цих нещасных, бо й то люде” (р-2); „Але наши люде не так вынни, як вы их вынуватыте” (р-3); ,Люде давно вже вечеряли, а в Якимовій хаті й забули, який сьогодня день” (р-17).

2. Приголосні д, т, 3, с, ст, як відомо, вже в найдавніші часи переходили у відповідні шиплячі: д $\rightarrow$ дж; т $\rightarrow$ ч; $\mathbf{3} \rightarrow$ ж; с $\rightarrow$ ш; ст $\rightarrow$ щ. Ці шиплячі рефлекси зберігаються в сучасній українській мові, зокрема в літературній і в багатьох говорах: ходжу, прошу, ненавиджу тощо. У ранніх оповіданнях М. Коцюбинського дієслівні форми 1-ої особи однини теперішнього часу дієслів II дієвідміни подано без чергування [д], [т], [3], [с] із відповідними шиплячими як у більшості південно-східних говорів, а також деяких південно-західних, напр.: „- Ну, земляче, ставай у мене, колы хочешь. Платою не скрывдю” (p-1); „А з ганку вже гукає дядько: „Муся, Муся! А ходы но лышень, я тоби щось покажу”. Пидходю" (р-3). У цих же творах письменника натрапляємо на форми типу хожу, сижу, де чергування відбулося, але фонема [дж] заступається фонемою [ж], що характерно для полтавських, південнокиївських і середньочеркаських говірок ${ }^{9}$, напр.: „А баба погукуе: „Хиба я ззим вам кавалок печи, чы буду зимоваты? Як посыжу якій тиждень...” (p-2), „Хожу я на воли - не дышу, а несыто ковтаю свиже повитря, упываюся и ным, и сонцем, и прохолодою” (p-3).

4. Форма Ор. відм. однини іменників на -ом (-ём, -ем) - жалём, вогнём, злодіём тощо, напр.: „Андрійко іи за косы, шарпае, а у самого очи так и блищать недобрым вогнём...” (р-1); „И те „щось” зовсим не пахло щзастём, достатком, спокоём, на що має право кожний чоловік” (р-2); „Прыхылыть свою стомлену кильканедильным неспанём голову до подушки и нибе дримає...”; „... и якись мріи насуваються идна за другою, оточують якимсь то спокийным, то пекучым счастем твое серце" (р-3).

5. Уживання закінчення -ів замість нульової флексії у формах Род. від. множини іменників жіночого роду I відміни, напр.: „Багато на свити таких бабив” (p-2). За аналогією вживання закінчення -ів замість нульової флексії у формах Род. відм. множини іменників чоловічого роду II відміни: мищзанив, цуыганив, напр.: „... гурмы усякого люду: панив, мищзанив, москалив, цъыганив, мужыкив, жыдив..." (p-1).

\footnotetext{
${ }^{9}$ С. П. Бе в з ен ко, Украӥнська діалектологія, Київ 1980, с. 71-72.
} 
6. Уживання прикметниково-прислівникового суфікса -ійш-, -ішч- та -чдля вираження вищого та найвищого ступенів порівняння замість суфікса -іш-:

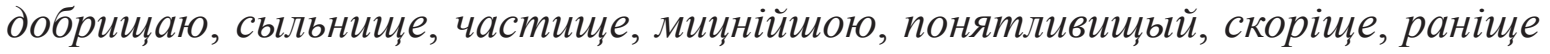
тощо, наприклад: „... та ще така в мене собача натура, що як пьяный, то зараз добрищзаю...”; „... щоб мицнійшою здавалась” (р-1); „Та хто вас, бабо, візьме у Сороку? - голоснище каже мама”; „Хочь на піч вилізте, може, там трохи тепліще....” (р-2); „Багато сонця, без миры чыстого повитря, на округы добро - й чоловик добрищаєе”; „Меньчый - билявеньке таке: роздзявыло рота, заклало назад рученята и трымає в ных возыка” (p-3); „... трохи повеселійшав: за три карбованці можна було відібрати від шевця жінчині чоботи” (р-17); „Йій хтілося скоріще діждатися ранку” (р-18); „Ляжу зараз спати, щоб завтра раніще прокинутися, - подумала Харитя й, поставивши коло мами воду на ніч, лягла на лаву" (p-18).

7. Уживання дієприкметникового суфікса -ан- у віддієслівних прикметниках замість суфікса -ен-, напр.: заваляне, выкладянных, одягняный, замучанылм, нахиляний, наприклад: „Гуркитня брычок по выкладянных каминямы вулыцямы, высоки будынкы, велыки крамныци...”; „... все те я виддам бидным, замучаным сельским дитям и их темным батькам та мамам” (p-1); ,3-за дверей виткнулось спершу відро, до половини виповнене водою, далі русява голова дівчинки, нахиляна вбік до відра, а далі права рука, піднята трохи догори” (р-18); „Срібний промінь місячний тихо сяє на білій головці дівчинки, всміхається до нових червоних кісників, гуляє по смуглявому видочку та білих дрібненьких зубках, що виглядають з-за розтуляних повних уст, Харитя спить солодким сном" (p-18); „Вмить якось дуже жаль стало єі слабої матері, дужче заболів той пальчик, що втяла серпом, заболіли ноги, наколяні стерньою ..." (р-18).

8. У рукописах ранніх оповідань письменника виявляємо форми минулого часу з залишками колишнього перфекта, напр.: „Так ем змерзла, так ем змерзла, що й... А-а-а!”; „Та вже сегодня не дійду. Змерзла-м дуже” (p-2). „А, здоров! Добре зробывесь, що прыйшов” (р-3).

9. Наявність флексії -и замість -і у формі родового відмінка однини іменників III відміни, напр.: „В печі палав вогонь і червоним язиком лизав челюсти” (p-18); „А Харитя й справді заходилася коло вечері. Змила в мисчині жменьку пшона, вкинула щіпку соли та дві-три бараболі, налляла горщик водою і приставила його до вогню” (р-18); „Незабаром мати Хариті одужала. Молодиці вижали удовине жито, хрещений батько Харитин звіз хліб в стодолу, і сироти вже не боялись голодної смерти" (р-18).

10. У південно-західних діалектах, для яких властиві аналітично-особові форми минулого часу, спостерігаємо й відмінності у формах умовного способу, що значною мірою нагадують відмінності у формах минулого часу. Так, у них умовна частка би приєднує до себе особові енклітики в 1-й та 2-й особах однини й множини. В оповіданні, зокрема, це бис' (2-а ос. однини): „Як бы ты не попав до нас, або до таких як мы, то може и пропавбысь" (p-1).

Аналіз пізніших рукописів письменника засвідчує, що деякі риси подільського говору зникають з його мови, а саме:

1. Слово ичілувати М. Коцюбинський уже пише через i: „I, сповнена радісним почуттям, підійшла стиха до чоловіка та поцілувала в мокре чоло” (р-197); „Зараз загриміли кріселка, і схилились над ним, циілуючи руки ...” (p-198).

2. Відсутність випадіння звука або групи звуків у дієслові хотіти, в середині присудкового слова треба, в частці нехай: „Доря їм заважав. Вони хотіли, 
щоб він швидше йшов спати” (р-197); „Вона звикла до думки. Подумати тільки: подивитись, як будуть вішать людину. Вона і сама б хотіла. Ах, Дорька, щасливий...” (р-197); „Йому хотілося їсти, як молодому двадцятилітньому хлопцю...” (р-199); „Сірі очі, трохи холодні і вже пригаслі, плавали на білках серед червоних жилок, і се його турбувало: «Треба знову класти примочку!»” (p-199); „Треба оборонятись. Треба стріляти із револьверів і всіх перебити...” (р-69); „Але він не зрадів: йому більше вже хотілося хмар і дощу, ніж сонця. Чорт бери сіно, нехай пропадає!...” (р-199). Однак зауважимо, що інколи явище синкопи трапляється й у пізніших творах: „Він плутав, кричав на Дорю, тицяв грубим пальцем в задачник, наче хтів роздушити всіх трьох купців...” (р-197).

3. У дієсловах 3-ої особи однини й множини теперішнього часу й 2-ої особи множини наказового способу вже послідовно письменник пише ь (м'який знак).

4. Відсутність твердості р перед голосними: „А проте мусив витягатися в струнку та козиряти тому шмаркачеві через те тільки, що був сином його начальства” (р-197); „Злегка обдряпаний твердим холодом гудзиків і погон, Доря припав з довір'ям до батька (р-197); „Софії Петрівні неприємно було дивитись, як Жан їсть неохайно, лишаючи в вусах шматки буряків, і вона повернулась до сина” (р-199); „Однак вдома і не думали подавати вечерю” (p-199); „Я бачу руки, я бачу очи, що благають рятунку...” (р-69).

5. Відсутність вставних вставних л', н’ після губних приголосних: „Тепер він опамятався і міг говорити” (р-69); „Першим опамятавсь поліцмейстер” (p-197).

6. Пасивні дієприкметники минулого часу М. Коцюбинський пише вже через суфікс -ан-, а не -ен-, як у ранніх творах: „Скрізь, де вони проходили по під освітлені вікна й одчинені двері, до них приставали жінки й чоловіки; діти бігли за ними, наче курява” (р-69); „Нарешті жінка хитнулась, одділена од дитини" (р-197).

Отже, вивчення мови творів за рукописною спадщиною, а не за творами різних років видання, дає змогу розширити перелік мовних особливостей, поданого в Курсі історії украӥнської літературної мови. Лише в рукописах, а не у виданнях радянського часу, можемо зафіксувати низку рис, що маркують ідіостиль письменника: вживання стверділого кінцевого [т'] у дієсловах 3-ої особи однини й множини теперішнього часу й 2-ої особи множини наказового способу, неподовження приголосних в іменниках середнього роду II відміни, позиції після голосних перед давнім закінченням -ьје, вживання закінчення -е у слові люди, прикметниково-прислівникового суфікса -ійш-, -ішч- та -ч- для вираження вищого та найвищого ступенів порівняння, вживання форм минулого часу із залишками колишнього перфекта тощо.

Мова автора й мовлення персонажів аналізованих оповідань репрезентує низку діалектних рис південно-західного наріччя, яких у перших літературних спробах значно більше, ніж у творах пізніших. Як засвідчує фактичний матеріал, мова оповідань унормована, але й не позбавлена рис подільського говору, що був рідним для М. Коцюбинського, хоча з розвитком й удосконаленням свого стилю він намагався замінювати діалектні форми на літературні. 